\title{
Neuropeptide B (NPB) and neuropeptide W (NPW) system in cultured rat calvarial osteoblast-like (ROB) cells: NPW and NPB inhibit proliferative activity of ROB cells
}

\author{
AGNIESZKA ZIOLKOWSKA, MARCIN RUCINSKI, MARIANNA TYCZEWSKA and LUDWIK K. MALENDOWICZ
}

Department of Histology and Embryology, Poznan University of Medical Sciences, 6 Swiecicki St., 60-781 Poznan, Poland

Received July 24, 2009; Accepted September 4, 2009

DOI: 10.3892/ijmm_00000292

\begin{abstract}
Neuropeptides B (NPB) and W (NPW) have been identified as endogenous ligands of two G-protein-coupled receptors, neuropeptides B/W receptor 1 (NPBWR1, formerly known as GPR7) and neuropeptides B/W receptor 2 (NPBWR2, formerly known as GPR8). In rodents where NPBWR2 is absent, its counterpart is named the similar to neuropeptides $\mathrm{B} / \mathrm{W}$ receptor 2 (similar to NPBWR2, formerly GPR8-like). Both NPB and NPW play a role in the control of feeding, neuroendocrine axis functions, memory and learning processes as well as in pain regulation. The present study aimed to investigate the expression of NPB, NPW, NPBWR1 and the similar to NPBWR2 genes in cultured rat calvarial osteoblastlike (ROB) cells and the effects of both peptides on proliferative activity and osteocalcin secretion by ROB cells. Classic RT-PCR technique revealed the presence of ppNPB mRNA, ppNPW mRNA, and NPBWR1 mRNA, but not similar to NPBWR2 mRNA in ROB cells. QPCR revealed gradual (days 7,14 and 21 of culture) increase of the ppNPB gene expression, while expression of ppNPW gene was the highest at day 14 and was comparable to that seen in freshly isolated cells. In ROB cells, expression of NPBWR1 gene was notable at day 7 of culture, lower at day 21, and negligible at day 14. Neither NPB nor NPW changed osteocalcin secretion by cultured osteoblast-like cells while both neuropeptides inhibited their proliferative activity. Results of the present study suggest that the systems of NPW, NPB and NPBWR1 directly regulate proliferative activity of cultured rat calvaria osteoblastlike cells. The physiological significance of this osteoblastic system remains unclear, and requires further investigation.
\end{abstract}

\section{Introduction}

Neuropeptide B/W receptor 1 (NPBWR1) and neuropeptide $\mathrm{B} / \mathrm{W}$ receptor 2 (NPBWR2) are two structurally related orphan

Correspondence to: Professor Ludwik K. Malendowicz, Department of Histology and Embryology, Poznan University of Medical Sciences, 6 Swiecicki St., 60-781 Poznan, Poland E-mail: 1km@amp.edu.pl

Key words: neuropeptide B, neuropeptide W, NPBWR1, similar to NPBWR2, osteoblast-like cell culture, osteocalcin, proliferation receptors linked to protein G. In rodents NPBWR2 is absent, and its counterpart is named similar to neuropeptide $\mathrm{B} / \mathrm{W}$ receptor 2 (NPBWR2 like). Endogenous ligands of these receptors have been identified as neuropeptide B (NPB) and W (NPW). NPB is 29 amino acid residues long and uniquely modified with bromine. NPW has been identified in two molecular forms of 23 and 30 amino acids (NPW23 and NPW30, respectively) (1-6).

Both at the mRNA and protein levels, the systems of NPB, NPW and their receptors were found to be widely distributed. Expression of its components was observed by others in the brain and alimentary tract (2,7-14). Both NPB and NPW affect food intake and energy expenditure (15-18). Those peptides and their receptors are also present in the neuroendocrine system and regulate its function. In this regard, involvement of both NPB and NPW in regulating hypothalamo-pituitaryadrenocortical axis is well recognised (17,19-27).

Numerous neuropeptides involved in energy homeostasis are also recognized as regulators of bone metabolism in animals and humans. Recent data suggest that bone and energy metabolisms exert reciprocal regulations and such an interrelationship was observed between osteocalcin and insulin (28). NPB, NPW and their receptors are expressed in pancreatic islets of the rat and NPW affects insulin secretion both in vivo and in vitro $(20,25,29)$. To our knowledge there are no data on the presence of NPB and NPW and their receptors in the major cell types of the bone. Therefore the present work aimed to examine the expression of that system in cultured rat calvaria osteoblastlike cells (ROB) and its possible role in regulating ROB cell functions.

\section{Materials and methods}

Chemicals. NPB29 and NPW23 were purchased from Phoenix Pharmaceuticals (Belmont, CA, USA). If not otherwise stated, the remaining reagents were from Sigma-Aldrich (St. Louis, MO, USA) or POCh (Gliwice, Poland).

Animals. Two day-old Wistar rats, born in our animal facilities, were used. The local ethics committee for animal studies approved the study protocol.

ROB cell culture. The technique was that described earlier (30-34) with minor modifications. Briefly, calvarias of 8 2-day-old rats were placed in DMEM (Gibco, UK), and the 
Table I. QPCR analysis of NPB, NPW, NPBWR1, similar to NPBWR2 and hypoxanthine-guanine phosphoribosyl transferase (HPRT) mRNAs in cultured ROB cells.

\begin{tabular}{|c|c|c|c|c|c|}
\hline cDNA & $\begin{array}{c}\text { Genbank } \\
\text { accession number }\end{array}$ & $\begin{array}{l}\text { Primer or } \\
\text { probe }\end{array}$ & $\begin{array}{l}\text { Primer or probe sequence }\left(5^{\prime}-3^{\prime}\right) \\
\text { (Universal probe library number) }\end{array}$ & Position & $\begin{array}{l}\text { PCR product } \\
\text { size }(\mathrm{bp})\end{array}$ \\
\hline \multirow[t]{2}{*}{ NPB } & NM 153293 & $S$ & CGGGATCCCACCACTACTC & $80-98$ & 245 \\
\hline & & A & GAAGACGTCCGCCTTACACT & $305-324$ & \\
\hline \multirow[t]{2}{*}{ NPW } & NM 153294 & $S$ & ACCTGAGCAGTCGCTAAGCTTT & $489-510$ & 150 \\
\hline & & A & CATCGGTTCTTGAGACGGTC & $619-638$ & \\
\hline \multirow[t]{2}{*}{ NPBWR1 } & NM 001014784 & $\mathrm{~S}$ & CATCTGCGCCCTCTATATCA & $660-679$ & 220 \\
\hline & & A & GAAGTAAGAGATGCCGATGACC & $858-879$ & \\
\hline \multirow[t]{2}{*}{ similar to NPBWR2 } & XM 230970 & $\mathrm{~S}$ & CAGCTCTCTTAGCCCAAGTGTAAGG & $24-48$ & 180 \\
\hline & & A & TGGTTCAGGGCAAACACATTAGTTA & $179-203$ & \\
\hline \multirow[t]{3}{*}{ HPRT } & NM 012583 & $\mathrm{~S}$ & CAGTCAACGGGGGACATAAAAG & $391-412$ & 146 \\
\hline & & A & ATTTTGGGGCTGTACTGCTTGA & $515-536$ & \\
\hline & & probe & TGGTGGAG $(22)$ & $417-426$ & \\
\hline
\end{tabular}

Oligonucleotide sequences for sense (S) and antisense (A) primers are shown.

connective tissue was removed. Calvarias were then cut into small fragments, which were dissociated to cell suspensions by enzymatic digestion with $0.1 \%$ collagenase-I (Sigma-Aldrich) for $30 \mathrm{~min}$ at $37^{\circ} \mathrm{C}$. ROB cells were harvested by centrifugation and resuspended in DMEM supplemented with $\mathrm{NaHCO}_{3}, 6 \%$ fetal calf serum (FCS) and antibiotic-antimycotic solution. Cells were then plated in culture dishes (Nalge Nunc International, Denmark, $1 \times 10^{4}$ cells/dish), and cultured for 21 days at $37^{\circ} \mathrm{C}$ in an humidified atmosphere of $95 \%$ air $-5 \% \mathrm{CO}_{2}$, medium was changed every other day (35). The experiments were performed on freshly isolated cells (QPCR only) and cells were harvested at days 7, 14 and 21 of culture. Before sampling, cells were maintained in medium without FCS for $48 \mathrm{~h}$. In such medium, osteoblasts were exposed for $48 \mathrm{~h}$ to various concentrations of NPB and NPW.

Characterization of $R O B$ cell culture by double immunofluorescence microscopy. Isolated osteoblasts were placed into LabTek ${ }^{\mathrm{TM}}$ Slide Chamber ${ }^{\mathrm{TM}}$ (Nalge Nunc International), and incubated as described above. Immunofluorescence was performed on ROB cells cultured for 14 days. Cells were

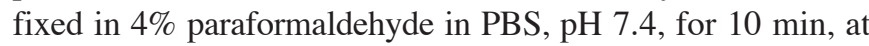
room temperature. Then slides were washed 3 times for $5 \mathrm{~min}$ in PBS and subsequently preincubated in PBS with $5 \%$ bovine albumin for $30 \mathrm{~min}$. In a humidified chamber they were incubated for $18 \mathrm{~h}$ in $4^{\circ} \mathrm{C}$ with primary antibodies against osteonectin and collagen $1 \alpha$ (Acris Antibodies $\mathrm{GmbH}$, Germany) in concentrations of 1:400. After incubation, slides were washed in PBS 3 times for $5 \mathrm{~min}$. As secondary antibodies goat anti-rabbit MFP488 (absorption wavelength, $503 \mathrm{~nm}$; emission wavelength, $524 \mathrm{~nm}$ ) and goat anti-mouse MFP590 (absorption wavelength, $597 \mathrm{~nm}$; emission wavelength, $624 \mathrm{~nm}$ ) (MoBiTech, Göttingen, Germany), respectively, in concentration of 1:1,000 (60 min, room temperature), were used. Slides were then washed in PBS 3 times for $5 \mathrm{~min}$, coverslips were mounted with a drop of mounting medium for fluorescence with DAPI (Santa Cruz Biotechnology, Santa Cruz, CA, USA).
Reactions were documented using Axiolmager Z1 microscope with ApoTome system (Carl Zeiss AG, Germany).

Osteocalcin determination. Osteocalcin concentrations in the culture medium were estimated using a rat osteocalcin EIA kit (Biomedical Technologies Inc., Stoughton, MA, USA). The sensitivity of the assay was $0.5 \mathrm{ng} / \mathrm{ml}$, and inter- and intra-assay CVs, 7 and 4\%, respectively.

Cell proliferation. Proliferation rate of ROB cells was measured by two methods. In the first method, the EZ4U Nonradioactive Cell Proliferation and Cytotoxic Assay kit (Biomedica, Vienna, Austria) was employed (36). Cultured cells were incubated for 90 min with EZ4U, and formazan derivatives production, which is linearly related to the cell number, was measured at $490 \mathrm{~nm}$ wavelength in a microplate autoreader EL-13 (Bio-Tek Instruments, Winooski, VT, USA). It is worthy to emphasize that EZAU assay system is highly compatible with the standard ${ }^{3} \mathrm{H}$-thymidine incorporation assay. In the second method, cell proliferation was studied using a colorimetric bromodeoxyuridine (BrdU) kit (5-Bromo-2' deoxy-uridine Labeling and Detection Kit III, Roche Diagnostics). Cells were incubated with BrdU for $6 \mathrm{~h}$ and subsequently fixed with methanol $\left(30 \mathrm{~min},-20^{\circ} \mathrm{C}\right)$. After fixative removal, cells were incubated with nuclease $\left(30 \mathrm{~min}, 37^{\circ} \mathrm{C}\right)$. After washing, cells were incubated with Anti BrdU-POD (30 min, $37^{\circ} \mathrm{C}$ ). Cells were washed 3 times, incubated with substrate for $10 \mathrm{~min}$ and then extinction was measured at $490 \mathrm{~nm}$.

Conventional RT-PCR and QPCR. Methods applied were described earlier (21,37-41). Applied primers for studies of NPB, NPW, NPBWR 1 and similar to NPBWR2 gene expression (Table I) were purchased from the Laboratory of DNA Sequencing and Oligonucleotide Synthesis, Institute of Biochemistry and Biophysics, Polish Academy of Sciences, Warsaw. The hypoxanthine-guanine phosphoribosyl transferase (HPRT) gene was used as a reference to normalize data. 
COLLAGEN $1 \alpha$

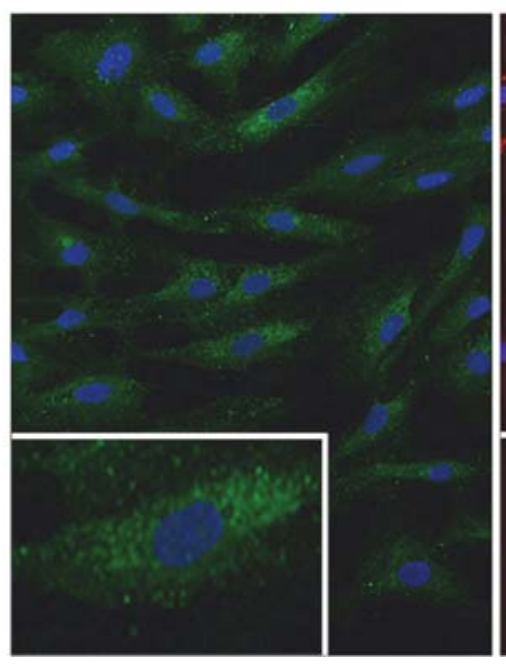

OSTEONECTIN

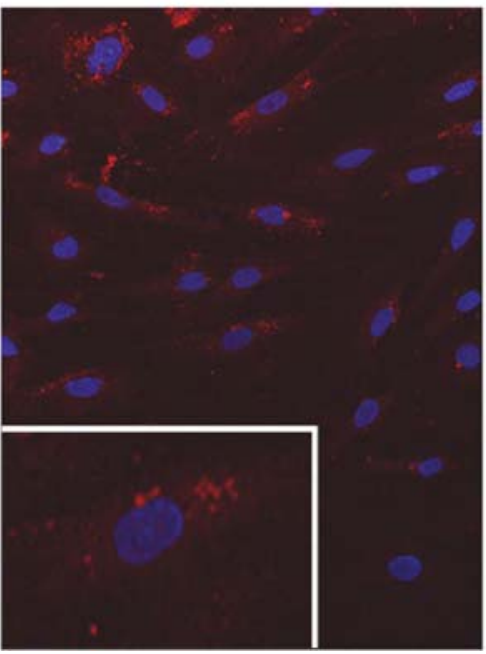

SUPERIMPOSED

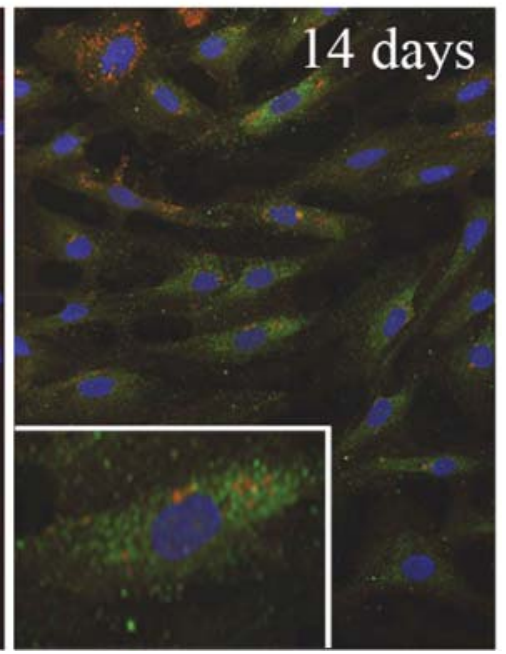

Figure 1. Double immunofluorescence microscopy illustrating the colocalization of collagen 1 $\alpha$ and osteonectin in cultured calvaria rat osteoblast-like cells during differentiation (day 14) stage. Cultures were fixed in 4\% paraformaldehyde in PBS, pH 7.4, for 10 min at room temperature and double labeled with primary antibodies against osteonectin and collagen $1 \alpha$, and followed by goat anti-rabbit MFP488 and goat anti-mouse MFP590 secondary antibodies. Coverslips were mounted in medium for fluorescence with DAPI. Reactions were documented using Axiolmager Z1 microscope with ApoTome system. Collagen $1 \alpha$, green; osteonectin, red; nuclei, blue. Colocalization was determined by merging green and red pictures to give yellow/orange stained cells. Magnification $\sim \mathrm{X} 400$, inserts $\sim \mathrm{x} 1000$.

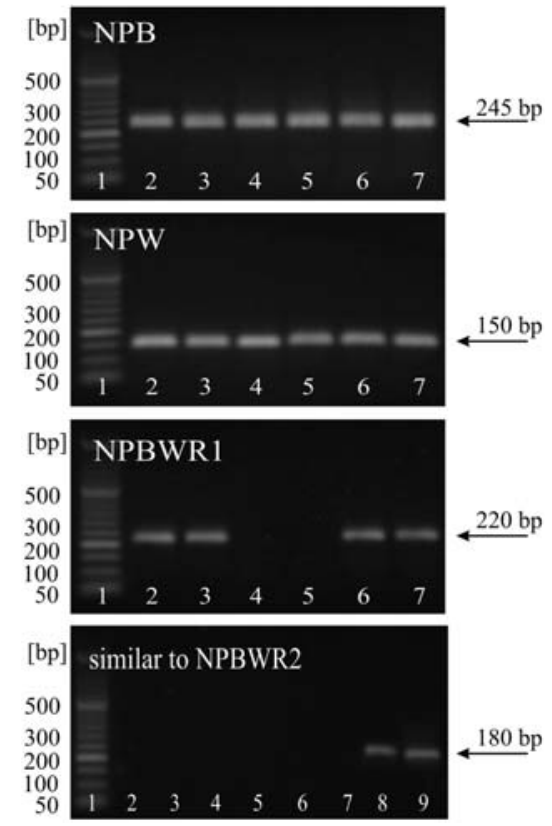

Figure 2. Ethidium bromide-stained $2 \%$ agarose gel showing cDNA amplified with rat specific primer from RNA of ROB cells cultured for 7, 14 and 21 days. Lane 1, size marker (O'Range Ruler 50 bp DNA Ladder; MBI Fermentas, Lithuania); lanes 2 and 3, day 7; lanes 4 and 5, day 14; lanes 6 and 7, day 21 . Lines 8 and 9, positive controls (adrenal cortex) for similar to NPBWR2 receptor. Reaction products with expected size are seen: NPB, $245 \mathrm{bp}$; NPW, 150 bp; NPBWR1, 220 bp; similar to NPBWR2, 180 bp.

Statistics. Data are expressed as the means \pm SEM and their statistical comparison was done by the unpaired Student's t-test.

\section{Results}

As shown by double immunofluorescence microscopy, all cultured ROB cells contain collagen $1 \alpha$ and osteonectin, typical

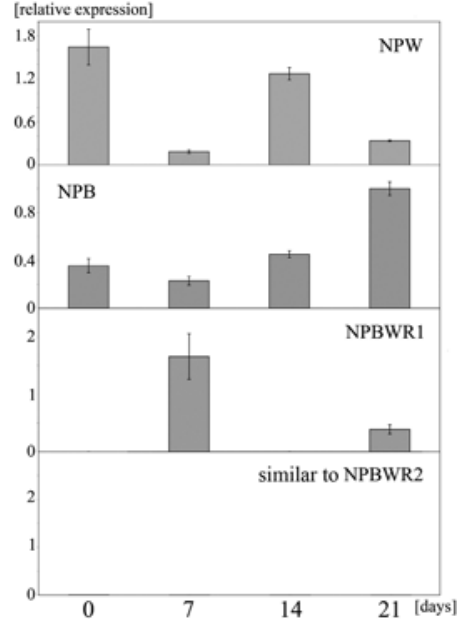

Figure 3. QPCR analyses of NPB, NPW, NPBWR1 and similar to NPBWR2 gene expression in the ROB cells at days 7, 14 and 21 of culture and in freshly isolated cells (day 0). All samples were amplified in triplicates, and HPRT gene expression was used as reference to normalize data. In each group $n=3$. Bars present means and $\mathrm{SE}$ is indicated.

markers of osteoblasts (Fig. 1). Such a pattern of immunofluorescence was observed at days 7, 14 and 21 of culture. Both peptides were mainly present in secretory granules, a number of which differed markedly among individual cells. As evidenced by merging green and red pictures (to give yellow/ orange colour), both collagen $1 \alpha$ and osteonectin express a very high degree of colocalization.

Classic RT-PCR technique revealed the presence of ppNPB and ppNPW mRNA at days 7, 14 and 21 of ROB cell culture (Fig. 2). NPBWR1 mRNA, on the other hand, was present at days 7 and 21 of culture, while similar to NPBWR2 mRNA was not observed. The similar to NPBWR2 mRNA was expressed in the rat adrenal cortex, an organ used as a positive 


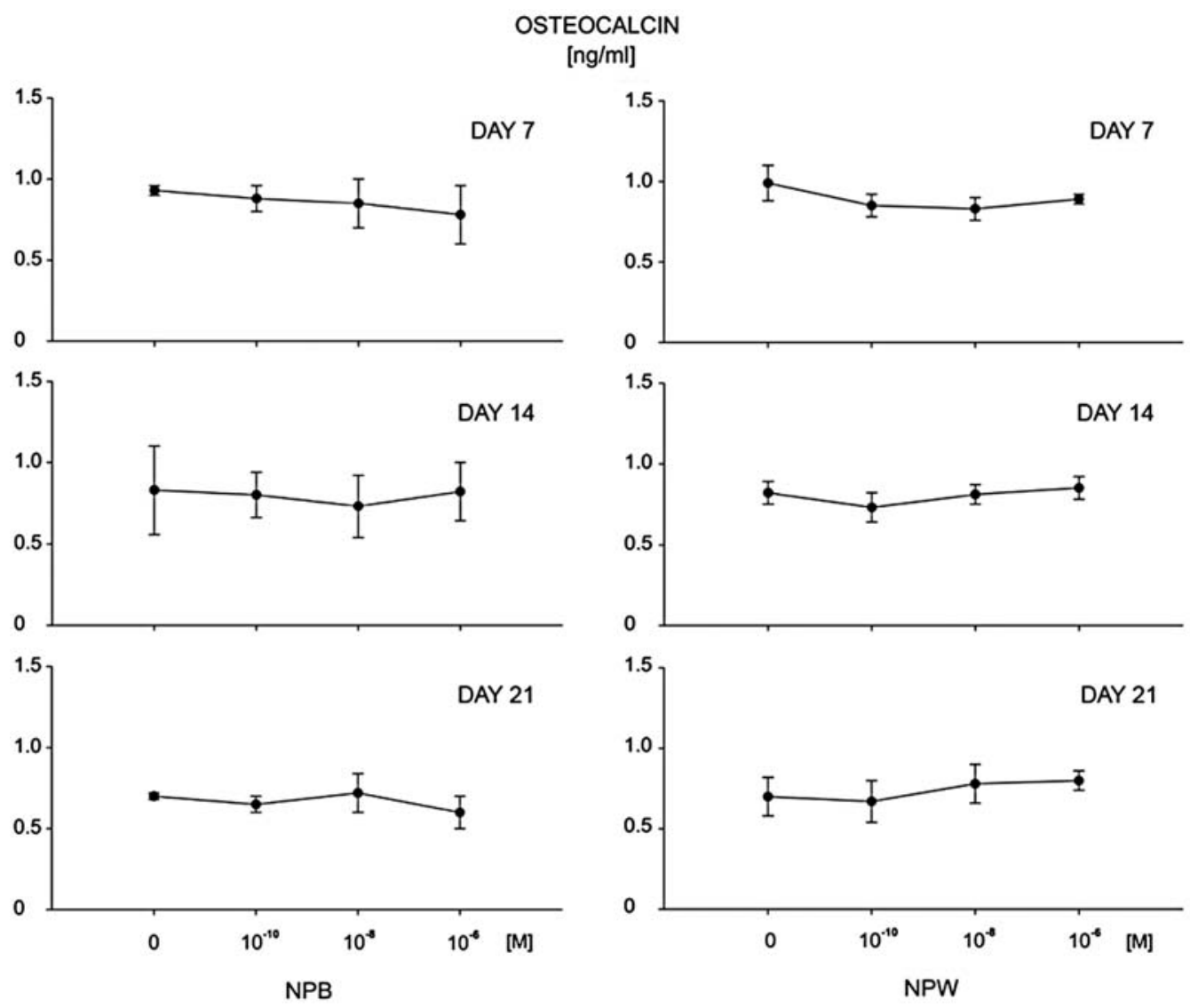

Figure 4. Effects of NPB and NPW on osteocalcin secretion by cultured ROB cells. Cells were exposed to tested compounds for $48 \mathrm{~h}$ in FCS stripped of medium. Neuropeptides were added to culture $48 \mathrm{~h}$ before medium collecting at days 7,14 and 21. Data are expressed as means \pm SEM, $\mathrm{n}=6$. Statistical comparisons (in relation to control) were done by the unpaired Student's t-test, all differences statistically nonsignificant.

control. With specific primers, RNA amplification by means of RT-PCR revealed the presence of reaction products with expected sizes: NPB, 245 bp; NPW, 150 bp; NPBWR1, $220 \mathrm{bp}$, and similar to NPBWR2, $180 \mathrm{bp}$.

In freshly isolated rat calvaria osteoblasts, QPCR revealed relatively high expression of NPB and NPW genes while expression of NPBWR1 and similar to NPBWR2 genes was not identified (Fig. 3). Expression of NPB gene increased with the time of culture and at day 21 reached $\sim 2.5 \mathrm{x}$ higher level than seen in freshly isolated cells. When compared with freshly isolated osteoblasts, NPW gene expression at days 7 and 21 of culture was notably lower while at day 14 was similar to that seen in freshly isolated cells. Relatively high expression of NPBWR1 gene appeared at day 7 of culture, lower at day 21, and expression was negligible at day14. Expression of similar to NPBWR2 gene was not found throughout the entire period of isolation and culture of ROB cells.

To study whether NPB or NPW affect osteocalcin production, cultured $\mathrm{ROB}$ cells were exposed for $48 \mathrm{~h}$ to various concentrations of neuropeptides $\left(10^{-10}-10^{-6} \mathrm{M}\right)$. Neither NPB nor NPW changed osteocalcin concentrations in media analyzed at days 7, 14 and 21 of culture (Fig. 4). On the other hand, NPW at the highest concentration applied $\left(10^{-6} \mathrm{M}\right)$ exerted a notable inhibitory effect on proliferative activity of ROB cells at days 7, 14 and 21 of culture, while NPB exerted a similar effect only at day 14 (Fig. 5). It should be emphasised that both, MTT and BrdU incorporation methods gave very similar results.

\section{Discussion}

To our knowledge, the present study is the first to demonstrate the presence of ppNPB and ppNPW mRNA in freshly isolated and cultured rat calvaria osteoblast-like cells. In freshly isolated cells however, we did not find the presence of either NPBWR1 or the similar to NPBWR2 mRNA, and such a pattern of expression of both neuropeptides and their receptors in studied cells is puzzling. Furthermore, expression of either the NPB or NPW genes was found throughout the entire time of ROB cell culture, while NPBWR 1 gene was expressed only in distinct periods of observations (days 7 , proliferative stage and 21, mineralization stage) and that of the similar to NPBWR2 gene was absent.

As evidenced by double immunofluorescence microscopy, our studied cultures were composed exclusively of cells expressing collagen $1 \alpha$ and osteonectin, standard markers of osteoblasts (30,43-46). In such cultures the reciprocal expression of NPW and NPBWR1 genes in freshly isolated and cultured ROB cells suggests an inverted interrelationship between the two genes. The studied osteoblast-like cells, high expression of the NPW gene at days 0 and 14 of the experiment was accompanied by very low or negligible expression of NPBWR1. This finding suggests a potent down-regulation of NPBWR1 by NPW. No such interrelationship was observed between the NPB and NPBWR1 genes expression. On the contrary, expression of the NPB gene gradually increased in the course of culture and was not related to expression of the remaining studied genes. 


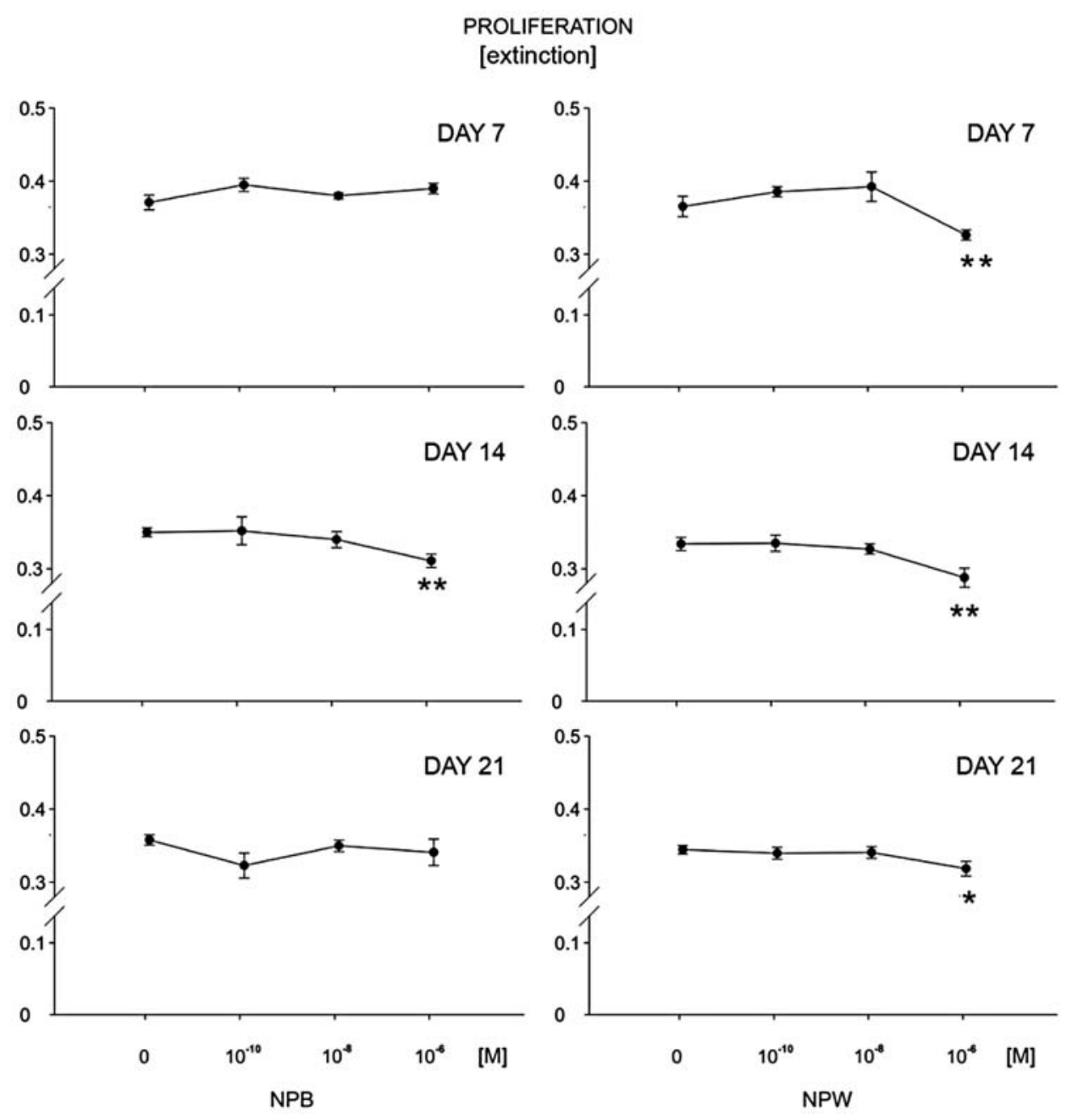

Figure 5. Effects of NPB and NPW on proliferative activity (extinction) of cultured ROB cells. BrdU incorporation method. Cells were exposed to tested compounds for $48 \mathrm{~h}$ in FCS stripped of medium. Neuropeptides were added to culture $48 \mathrm{~h}$ before medium collecting at days 7, 14 and 21. Data are expressed as means $\pm \mathrm{SEM}, \mathrm{n}=6$. Statistical comparisons (in relation to control) were done by the unpaired Student's t-test, ${ }^{*} \mathrm{p}<0.05,{ }^{* *} \mathrm{p}<0.02$.

High structural homology of both neuropeptides (NPB and NPW) and their receptors (NPBWR1 and the similar to NPBWR2) suggests that each ligand and receptor are partially overlaping and also have specific roles in this signaling system. It is well documented that NPB activates and binds to both human NPBWR1, and with lower affinity to NPBWR2 $(5,6)$. Likewise, NPW23 and NPW30 interact with those receptors, although with lower affinity. To test the possible roles of both neuropeptides in regulating ROB cell function, we exposed cultured cells for $48 \mathrm{~h}$ to various concentrations of NPB and NPW. In the FCS free culture medium both tested neuropeptides did not change osteocalcin secretion. Osteocalcin is one of the abundant noncollagenous matrix molecules in adult bone, and it is a specific marker for studying osteoblast differentiation $(46,47)$. Thus, obtained data suggest that neither NPB nor NPW affects the specialized function (osteocalcin secretion) of cultured ROB cells. On the contrary, exposure to rather high NPW concentration $\left(10^{-6} \mathrm{M}\right)$ resulted in potent inhibition of ROB cell proliferative activity at days 7, 14 and 21, while a similar effect with NPB was found only at day 14 . Thus, the obtained results suggest an inhibitory effect of NPW and NPB on the non-differentiated function of ROB cells, with NPW being more active. In this context it should be emphasised that notable differences in NPW and NPB actions on functioning of various cells were observed in adrenocortical and pancreatic islet cells (20,23-25). The present data expand these earlier observations.

Concomitant expression of neuropeptides and their NPBWR1 receptor suggests that both NPB and NPW paracrinally modulate biological functions of ROB cells. In this context it is noteworthy that NPW30 is present in blood and in the systemic vein of the rat its concentration is $\sim 0.42 \pm 0.7 \mathrm{fmol} / \mathrm{ml}$ (7). This finding suggests that NPW also affects rat osteoblast functions via endocrine mechanism. However, we can not rule out the other possible mode of NPW and NPB action on osteoblasts in vivo.

Recent reports indicate that peptides involved in regulation of energy homeostasis affect both bone formation and remodelling. These compounds may act via endocrine, paracrine or autocrine routes, as well as through the central nervous system. This last mode of action is mediated via the sympathetic system and was demonstrated among others for leptin and neuromedin U (48-55). As mentioned previously, NPB and NPW also belong to neuropeptides involved in regulation of energy homeostasis. Icv NPB or NPW administration affects food intake and energy expenditure $(4,6,14,16,18,19)$. In this 
regard, targeted disruption of the GPR7 gene leads to metabolic defects and adult-onset obesity and similar effects have been observed in NPB-null mice $(15,56)$. Moreover, icv administration of NPW stimulates plasma catecholamine concentrations in conscious rats and similar effects were observed at the adrenal medulla level $(24,26,27)$. Thus, it cannot be excluded that in vivo both NPB and NPW may also affect bone cell activity acting via the central nervous system.

In conclusion, our results suggest that the system of NPW, NPB and NPBWR1 directly regulates proliferative activity of cultured rat calvaria osteoblast-like cells. The physiological significance of this osteoblastic system remains unclear, and requires further investigation.

\section{References}

1. O'Dowd BF, Scheideler MA, Nguyen T, Cheng R, Rasmussen JS, Marchese A, Zastawny R, Heng HH, Tsui LC, Shi X, Asa S, Puy L and George SR: The cloning and chromosomal mapping of two novel human opioid-somatostatin-like receptor genes, GPR7 and GPR8, expressed in discrete areas of the brain. Genomics 28: 84-91, 1995.

2. Lee DK, Nguyen T, Porter CA, Cheng R, George SR, Brian F and O'Dowd BF: Two related G protein-coupled receptors. The distribution of GPR7 in rat brain and the absence of GPR8 in rodents. Molec Brain Res 71: 96-103, 1999.

3. Fujii R, Yoshida H, Fukusumi S, Habata Y, Hosoya M, Kawamata Y, Yano T, Hinuma S, Kitada C, Asami T, Mori M, Fujisawa $Y$ and Fujino M: Identification of a neuropeptide modified with bromine as an endogenous ligand for GPR7. J Biol Chem 277: 34010-34016, 2002.

4. Shimomura Y, Harada M, Goto M, Sugo T, Matsumoto Y, Abe M, Watanabe T, Asami T, Kitada Ch, Mori M, Onda H and Fujino M: Identification of neuropeptide $\mathrm{W}$ as the endogenous ligand for orphan G-protein-coupled receptors GPR7 and GPR8. J Biol Chem 277: 35826-35832, 2002.

5. Brezillon S, Lannoy V, Franssen JD, Le Poul E, Dupriez V, Lucchetti J, Detheux M and Parmentier M: Identification of natural ligands for the orphan $G$ protein-coupled receptors GPR7 and GPR8. J Biol Chem 278: 776-783, 2003.

6. Tanaka H, Yoshida T, Miyamoto N, Motoike T, Kurosu H, Shibata K, Yamanaka A, Williams SC, Richardson JA, Tsujino N, Garry MG, Lerner MR, King DS, O'Dowd BF, Sakurai T and Yanagisawa M: Characterization of a family of endogenous neuropeptide ligands for the $G$ protein-coupled receptors GPR7 and GPR8. Proc Natl Acad Sci USA 100: 6251-6256, 2003.

7. Mondal MS, Yamaguchi H, Date Y, Toshinai K, Kawagoe T, Tsuruta T, Kageyama H, Kawamura Y, Shioda S, Shimomura Y, Mori $\mathrm{M}$ and Nakazato M: Neuropeptide $\mathrm{W}$ is present in antral G cells of rat, mouse, and human stomach. J Endocrinol 188: 49-57, 2006.

8. Mondal MS, Yamaguchi H, Date Y, Tsuruta T, Shimbara T, Toshinai K, Shimomura Y, Mori M and Nakazato M: Ontogeny of a new enteric peptide, neuropeptide W (NPW), in the developing rat stomach. Regul Pept 145: 141-146, 2008.

9. Jackson VR, Lin SH, Wang Z, Nothacker HP and Civelli O: A study of the rat neuropeptide $\mathrm{B} /$ neuropeptide $\mathrm{W}$ system using in situ techniques. J Comp Neurol 497: 367-383, 2006.

10. Singh G and Davenport AP: Neuropeptide B and W: neurotransmitters in an emerging G-protein-coupled receptor system. Br J Pharmacol 148: 1033-1041, 2006.

11. Schulz S, Stumm R and Höllt V: Immunofluorescent identification of neuropeptide B-containing nerve fibers and terminals in the rat hypothalamus. Neurosci Lett 411: 67-71, 2007.

12. Takenoya F, Kitamura S, Kageyama H, Nonaka N, Seki M, Itabashi K, Date Y, Nakazato $M$ and Shioda S: Neuronal interactions between neuropeptide $\mathrm{W}$ - and orexin- or melaninconcentrating hormone-containing neurons in the rat hypothalamus. Regul Pept 145: 159-164, 2008.

13. Caminos JE, Bravo SB, García-Rendueles ME, Ruth González C, Garcés MF, Cepeda LA, Lage R, Suárez MA, López M and Diéguez C: Expression of neuropeptide $\mathrm{W}$ in rat stomach mucosa: Regulation by nutritional status, glucocorticoids and thyroid hormones. Regul Pept 146: 106-111, 2008.
14. Hondo M, Ishii M and Sakurai T: The NPB/NPW neuropeptide system and its role in regulating energy homeostasis, pain, and emotion. Results Probl Cell Differ 46: 239-256, 2008.

15. Ishii M, Fei H and Friedman JM: Targeted disruption of GPR7, the endogenous receptor for neuropeptides $B$ and $W$, leads to metabolic defects and adult-onset obesity. Proc Natl Acad Sci USA 100: 10540-10545, 2003.

16. Mondal MS, Yamaguchi H, Date Y, Shimbara T, Toshinai Y, Shimomura Y, Mori $M$ and Nakazato M: A Role for neuropeptide $\mathrm{W}$ in the regulation of feeding behavior. Endocrinology 144: 4729-4733, 2003.

17. Samson WK, Baker JR, Samson CK, Samson HW and Taylor MM: Central neuropeptide B administration activates stress hormone secretion and stimulates feeding in male rats. J Neuroendocrinol 16: 842-849, 2004.

18. Levine AS, Winsky-Sommerer R, Huintron-Resendiz S, Grace MK and de Lecea L: Injection of neuropeptide $\mathrm{W}$ into paraventicular nucleus of hypothalamus increases food intake. Am J Physiol Regul Integr Comp Physiol 288: 1727-1732, 2005.

19. Baker JR, Cardinal K, Bober C, Taylor MM and Samson WK: Neuropeptide W acts in brain to control prolactin, corticosterone, and growth hormone release. Endocrinology 144: 2816-2821, 2003.

20. Hochol A, Albertin G, Nussdorfer GG, Spinazzi R, Ziolkowska A, Rucinski M and Malendowicz LK: Effects of neuropeptide B and $\mathrm{W}$ on the secretion and growth of rat adrenocortical cells. Int J Mol Med 14: 843-847, 2004.

21. Hochol A, Belloni AS, Rucinski M, Ziolkowska A, Di Liddo R, Nussdorfer GG and Malendowicz LK: Expression of neuropeptides $\mathrm{B}$ and $\mathrm{W}$ and their receptors in endocrine glands of the rat. Int J Mol Med 18: 1101-1106, 2006.

22. Niimi M and Murao K: Neuropeptide $\mathrm{W}$ as a stress mediator in the hypothalamus. Endocrine 27: 51-54, 2005.

23. Andreis PG, Rucinski M, Neri G, Conconi MT, Petrelli L, Parnigotto PP, Malendowicz LK and Nussdorfer GG: Neuropeptides $B$ and $W$ enhance the growth of human adrenocortical carcinoma-derived NCI-H295 cells by exerting MAPK p42/p44-mediated proliferogenic and antiapoptotic effects. Int J Mol Med 16: 1021-1028, 2005.

24. Mazzocchi G, Rebuffat P, Ziolkowska A, Rossi GP, Malendowicz LK and Nussdorfer GG: G protein receptors 7 and 8 are expressed in human adrenocortical cells, and their endogenous ligands neuropeptides $\mathrm{B}$ and $\mathrm{W}$ enhance cortisol secretion by activating adenylate cyclase-and phospholipase $\mathrm{C}$-dependent signaling cascades. J Clin Endocrinol Metab 90: 3466-3471, 2005.

25. Rucinski M, Nowak KW, Chmielewska J, Ziolkowska A and Malendowicz LK: Neuropeptide W exerts a potent suppressive effect on blood leptin and insulin concentrations in the rat. Int $\mathrm{J}$ Mol Med 19: 401-406, 2007.

26. Yu NS, Kunitake T, Kato K, Nakazato M and Kannan H: Effects of intracerebroventricular administration of neuropeptide W30 on neurons in the hypothalamic paraventricular nucleus in the conscious rat. Neurosci Lett 415: 140-145, 2007.

27. Seki M, Kageyama H, Takenoya F, Hirayama M, Kintaka Y, Inoue S, Matsuno R, Itabashi K, Date Y, Nakazato M and Shioda S: Neuropeptide $\mathrm{W}$ is expressed in the noradrenalincontaining cells in the rat adrenal medulla. Regul Pept 145: 147-152, 2008.

28. Lee NK, Sowa H, Hinoi E, Ferron M, Ahn JD, Confavreux C, Dacquin R, Mee PJ, McKee MD, Jung DY, Zhang Z, Kim JK, Mauvais-Jarvis F, Ducy $\mathrm{P}$ and Karsenty G: Endocrine regulation of energy metabolism by the skeleton. Cell 130: 456-469, 2007.

29. Dezaki K, Kageyama H, Seki M, Shioda S and Yada T: Neuropeptide $\mathrm{W}$ in the rat pancreas: Potentiation of glucoseinduced insulin release and $\mathrm{Ca}(2+)$ influx through L-type $\mathrm{Ca}(2+)$ channels in beta-cells and localization in islets. Regul Pept 145: 153-158, 2008.

30. Boden SC, McCuaig K, Hair G, Racine M, Titus L, Wozney JM and Nanes MS: Differential effects and glucocorticoid potentiation of bone morphogenetic protein action during rat osteoblast differentiation in vitro. Endocrinology 137: 3401-3407, 1996.

31. Bodine PV and Komm BS: Tissue culture models for studies of hormone and vitamin action in bone cells. Vitam Horm 64: 101-151, 2002.

32. Kartsogiannis $\mathrm{V}$ and $\mathrm{Ng} \mathrm{KW}$ : Cell lines and primary cell cultures in the study of bone cell biology. Mol Cell Endocrinol 228: 79-102, 2004.

33. Ziolkowska A, Rucinski M, Di Liddo R, Nussdorfer GG and Malendowicz LK: Expression of the beacon gene in endocrine glands of the rat. Peptides 25: 133-137, 2004. 
34. Ziolkowska A, Carraro G, Rebuffat P, Spinazzi R, Nussdorfer GG, Rucinski M and Malendowicz LK: Beacon [47-73] inhibits glucocorticoid secretion and growth of cultured rat and human adrenocortical cells. Int J Mol Med 14: 457-461, 2004.

35. Ziolkowska A, Rucinski M, Pucher A, Tortorella C, Nussdorfer GG and Malendowicz LK: Expression of osteoblast marker genes in rat calvarial osteoblast-like cells, and effects of the endocrine disrupters diphenylolpropane, benzophenone-3, resveratrol and silymarin. Chem Biol Interact 164: 147-156, 2006.

36. Mosmann T: Rapid colorimetric assay for cellular growth and survival: application to proliferation and cytotoxicity assays. J Immunol Meth 65: 55-63, 1983.

37. Albertin G, Carraro G, Parnigotto PP, Conconi MT, Ziolkowska A, Malendowicz LK and Nussdorfer GG: Human skin keratinocytes and fibroblasts express adrenomedullin and its receptors, and adrenomedullin enhances their growth in vitro by stimulating proliferation and inhibiting apoptosis. Int J Mol Med 11: 635-639, 2003.

38. Tortorella C, Macchi C, Spinazzi R, Malendowicz LK, Trejter M and Nussdorfer GG: Ghrelin, an endogenous ligand for the growth hormone-secretagogue receptor, is expressed in the human adrenal cortex. Int J Mol Med 12: 213-217, 2003.

39. Rucinski M, Andreis PG, Ziolkowska A, Nussdorfer GG and Malendowicz LK: Differential expression and function of beacon in the rat adrenal cortex and medulla. Int J Mol Med 16: 35-40, 2005.

40. Rucinski M, Ziolkowska A, Neri G, Trejter M, Zemleduch T, Tyczewska M, Nussdorfer GG and Malendowicz LK: Expression of neuromedins $\mathrm{S}$ and $\mathrm{U}$ and their receptors in the hypothalamus and endocrine glands of the rat. Int J Mol Med 20: 255-259, 2007.

41. Hochol A, Tortorella C, Rucinski M, Ziolkowska A Nussdorfer GG and Malendowicz LK: Effects of neuropeptides B and $\mathrm{W}$ on the rat pituitary-adrenocortical axis: In vivo and in vitro studies. Int J Mol Med 19: 207-212, 2007.

42. Rodan GA and Noda M: Gene expression in osteoblastic cells. Crit Rev Eukaryot Gene Expr 1: 85-98, 1991.

43. Aubin JE, Liu F, Malaval L and Gupta AK: Osteoblast and chondroblast differentiation. Bone 17: 77-83, 1995

44. Hinoi E, Fujimori S, Takemori A and Yoneda Y: Cell death by pyruvate deficiency in proliferative cultured calvarial osteoblasts Biochem Biophys Res Commun 294: 1177-1183, 2002.

45. Sharma P, Solomon KR and Hauschka PV: High-throughput tool for discovery of bone regulating factors. Biotechniques 41 539-542, 2006.
46. Malaval L, Liu F, Roche P and Aubin JE: Kinetics of osteoprogenitor proliferation and osteoblast differentiation in vitro. $\mathrm{J}$ Cell Biochem 74: 616-627, 1999.

47. Nakamura A, Dohi Y, Akahane M, Ohgushi H, Nakajima H, Funaoka $\mathrm{H}$ and Takakura Y: Osteocalcin secretion as an early marker of in vitro osteogenic differentiation of rat mesenchymal stem cells. Tissue Eng Part C Methods 15: 169-180, 2009.

48. Ducy P, Amling M, Takeda S, Priemel M, Schilling AF, Beil FT, Shen J, Vinson C, Rueger JM and Karsenty G: Leptin inhibits bone formation through a hypothalamic relay: a central control of bone mass. Cell 100: 197-207, 2000.

49. Takeda S, Elefteriou F, Levasseur R, Liu X, Zhao L, Parker KL, Armstrong D, Ducy P and Karsenty G: Leptin regulates bone formation via the sympathetic nervous system. Cell 111: 305-317, 2002.

50. Cornish J, Callon KE, Bava U, Lin C, Naot D, Hill BL, Grey AB, Broom N, Myers DE, Nicholson GC and Reid IR: Leptin directly regulates bone cell function in vitro and reduces bone fragility in vivo. J Endocrinol 175: 405-415, 2002.

51. Gordeladze JO and Reseland JE: A unified model for the action of leptin on bone turnover. J Cell Biochem 88: 706-712, 2003.

52. Thomas T: The complex effects of leptin on bone metabolism through multiple pathways. Curr Opin Pharmacol 4: 295-300, 2004.

53. Hamrick MW, Della-Fera MA, Choi YH, Pennington C, Hartzell D and Baile CA: Leptin treatment induces loss of bone marrow adipocytes and increases bone formation in leptindeficient ob/ob mice. J Bone Miner Res 20: 994-1001, 2005.

54. Karsenty G: Convergence between bone and energy homeostases: leptin regulation of bone mass. Cell Metab 4: 341-348, 2006.

55. Sato S, Hanada R, Kimura A, Abe T, Matsumoto T, Iwasaki M, Inose $\mathrm{H}$, Ida T, Mieda M, Takeuchi Y, Fukumoto S, Fujita T, Kato S, Kangawa K, Kojima M, Shinomiya K and Takeda S: Central control of bone remodeling by neuromedin U. Nat Med 13: 1234-1240, 2007.

56. Kelly MA, Beuckmann CT, Williams SC, Sinton CM, Motoike T, Richardson JA, Hammer RE, Garry MG and Yanagisawa M: Neuropeptide B-deficient mice demonstrate hyperalgesia in response to inflammatory pain. Proc Natl Acad Sci USA 102: 9942-9927, 2005 